\title{
Development of Financial Technology through E-Payment System in India
}

\author{
D.O.I - 10.51201/Jusst12677 \\ http://doi.org/10.51201/Jusst12677 \\ Ms. Aanchal Nigam ${ }^{1}$, Dr. Zain Mehdi ${ }^{2}$, Dr. Syed Shahid Mazhar ${ }^{3}$ \\ ${ }^{1}$ Research Scholar, Integral University, Lucknow \\ ${ }^{2}$ Assistant Professor, Integral University, Lucknow \\ ${ }^{3}$ HOD, Department of Commerce \& Business Management, Integral University, Lucknow,
}

\begin{abstract}
A new phase of digital transformation has initiated in 2010 for the very first time with the financial technology innovation and known as IMPS. The expectations driven and E-payment system reached to a new hike with benchmark performance. Many explorations have been executed in the economy from e-wallets to insurtech, e-funding to agritech, blockchain to cryptocurrencies (bitcoin investments). These finnovations stepped out with a strong foundation in the economical scenario to make the digitization an inseparable part of our economy. This research study proposes an element of electronic on the payment as a disruptive. The research methodology followed is descriptive in nature and started with comparing the paradigm shift in payment system. The time period that has been taken to make this study ranges five years, i.e., (2015-2020) and data is based on secondary sources. Annual reports of RBI are being taken into consideration to understand the particular changes and consumer preferences and adaptations efficiently. The outcome of the study shows that there is some lack of qualities in old type of payment system due to which people felt a need to adapt themselves according to the changing reality of digitized world. This research study will help researchers to analyze the future trends of FinTech companies and to understand the ways for E-payment sector to get a growth capability specifically in India. It will also recommends the scope of future study that could be performed empirically to have an analytical result about the various aspects through which consumers make their choices of making digitally payment.
\end{abstract}

Keywords: Financial Technology, E-Payment System, NEFT, RTGS, CBC, Traditional Payment System.

\section{Introduction:}

First of all, it is FinTech which need an explanation because of the clarity for foundation that is required to establish for the descriptive study. The initiative to develop Financial Technology was taken into multi-phases. The researcher incorporated the history behind finnovation with the help of tabular representation for understanding the starting point of fintech and then introduction of it in India for the very first time.

In the words of Amer, Barberis \& Buckley (2015) the term financial technology or 'FinTech' entered in the market to give financial services to the customers at an ease through technological shifting from traditional to digital payment. According to the views of Blake \& Vanham (2016) Fintech is the use of technology considering the technological 
advancements to provide financial services. In the words of Murad (2015), he elaborated Fintechs as a kind of "nimble piranhas, each focusing on a small part of a bank's business model to attack".

\begin{tabular}{|c|c|c|}
\hline S.NO. & YEAR & FINTECH GENERATIONS \\
\hline 1. & 1886-1967 & $\begin{array}{l}\text { The very first events started to happen in this time lane like } \\
\text { evolution of Transatlantic cable, Fedwire in USA and the initiation } \\
\text { of Electronic Fund Transfer System. During 1950s, credit cards } \\
\text { came into fashion to lessen the burden of lump sum payment of } \\
\text { amount. American Express and Diner's Club are the sure shot } \\
\text { examples for this development. }\end{array}$ \\
\hline 2. & $1967-2008$ & $\begin{array}{l}\text { This era began with the establishment of world's very first digital } \\
\text { stock exchange to smoothen the functioning of the financial } \\
\text { markets effectively. SWIFT for decent telecommunication } \\
\text { activities, Mainframe computers for banking operations, and E- } \\
\text { commerce framework came into existence for satisfying customers. }\end{array}$ \\
\hline 3. & $\begin{array}{l}2008-A t \\
\text { present }\end{array}$ & $\begin{array}{l}\text { During this phase, the traditional banking system went aback due to } \\
\text { the digitalization that was happening and still is developing in } \\
\text { terms of technological advancements especially in urban areas. } \\
\text { This situation is becoming more interesting fortunately after the } \\
\text { invention of 'bitcoins', a virtual form of cryptocurrency to invest } \\
\text { money for more profit. Blockchain technology which refers to } \\
\text { electronic record of ledger transactions come to a new point of } \\
\text { maturity now giving opportunity to new businesses. } \\
\text { Many Fintech startups are in line to grab the benefits of this } \\
\text { financial advancement phase in the market. E-wallets, E-payment } \\
\text { system, UPIs etc. also are in rage at present moment. }\end{array}$ \\
\hline
\end{tabular}

The word 'FinTech' refers to improvement over traditional financial services. Financial Technology is an innovative disruption to satisfy consumers. This correlation of Finance and technology is known as Fintech. The global requirement of technological advancement brings Fintech into rage and a new era begins.

\subsection{Traditional Payment Problems}

The Central Bank of India and various E-Commerce platforms evolved an immediate need for digitalization of payment and settlement so as to satisfy the customers. Some of the major problems faced by the potential consumers are as follows- 


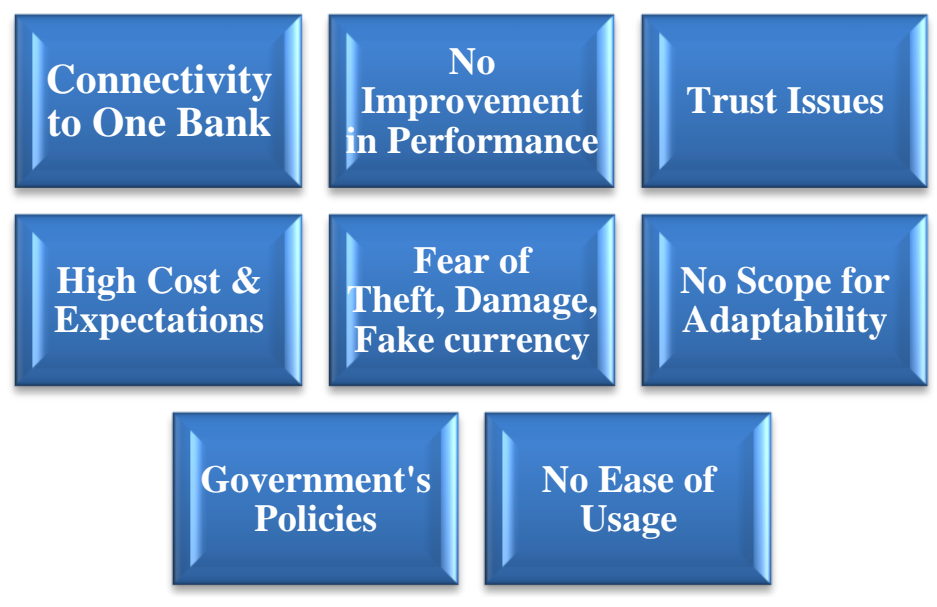

- Connectivity to One Bank- Due to account in a bank, the entire payment transaction related problem could only be solved by that particular bank. Customers are facing problem due to cash payment mode that is why digital revolution came into rage.

- No Improvement in Performance- As far as performance is concerned, monetary problems of bank customers always felt to just skip the long procedures to transfer or withdraw cash for use, and to avail that facility digital payment platforms were formed.

- Trust Issues- Due to the maximization of fake currency minting, the trust issues is developing with the users day-by-day. Still so many people are facing this issue with traditional payment system.

- High Cost \& Expectations- In all the procedures to provide traditional payment system, the cost that is incurred go on a hike which is very near to expensive system. That too, the expectations meet point of the whole system is quite low.

- Fear of Theft, Damage, Fake currency- There are so many small town people who are indulged in these illegal activities of fake currency provider and the paper notes are very delicate to use which can only be replaced with the modern technologies of payment making.

- No Scope for Adaptability- Basically the adaptations are correlated with the applicability. As far as payment is concerned, every time user wants to follow less rules.

- Government's Policies- The policies of the Government are subject to the profitability ratios that are being taken into consideration to allow over the public.

- No Ease of Usage- There is no ease in the usage of the traditional payment system that are being available for the public as a whole. Digitalisation will help a lot to solve these issues. 


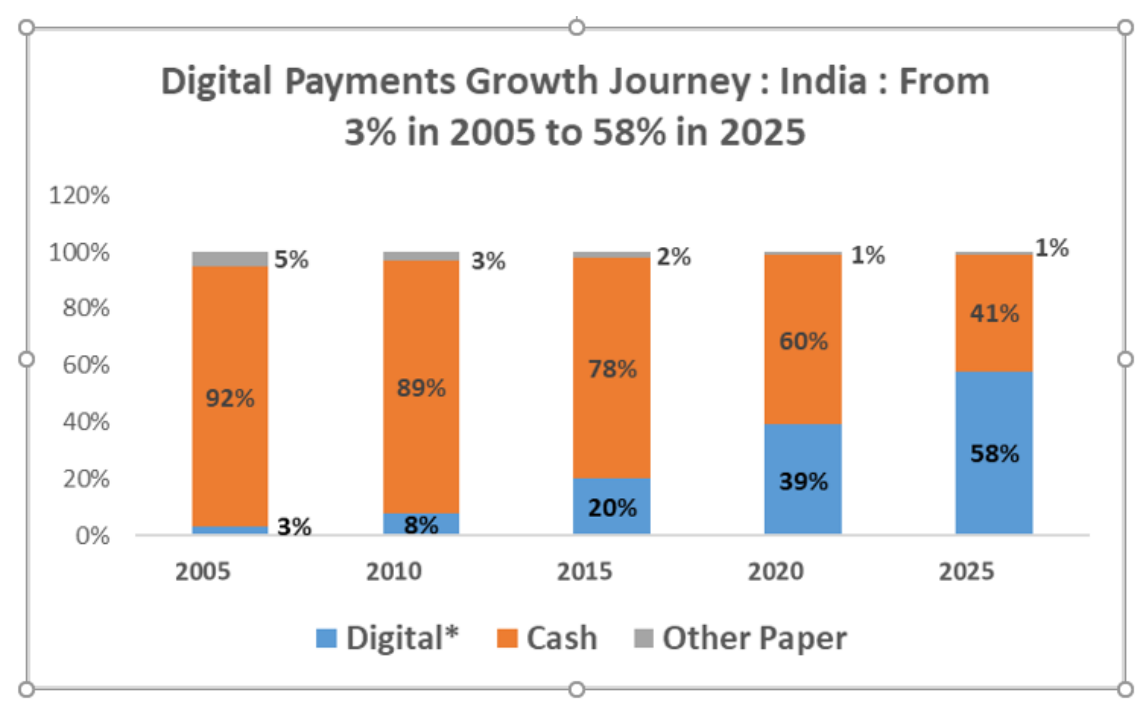

Figure 1: Digital Payment Growth Journey: India

Source: Community (NASSCOM Insights)

Form the above figure 1, given in the NASSCOM report, it can be estimated that till 2025 there will be enhanced growth in digital payment with 59\% over the cash payment which will be $41 \%$ or $1 \%$ for other paper based currencies. Due to the traditional paper based transactions many issues cannot be dissolved but as far financial technology is concerned, it is giving a new face to the Indian Payment Sector.

\subsection{RBI Statements Over Digital Payment Sector in India}

The RBI gave a proposal to establish a new PAN-India Umbrella Entity (NUE) for retail payment systems, which will be responsible for managing, handling and setting up new payment systems that includes ATMs, PoS, Aadhaar-based payments, and remittance services.(MEDICI, India FinTech Report 2020)

About $8.63 \%$ has been found for the e-payment gateways funding out of $\$ 2,467$ $\mathrm{Mn}$ which is less than the portion that has been provided to mobile/digital wallets, i.e. $78.68 \%$.

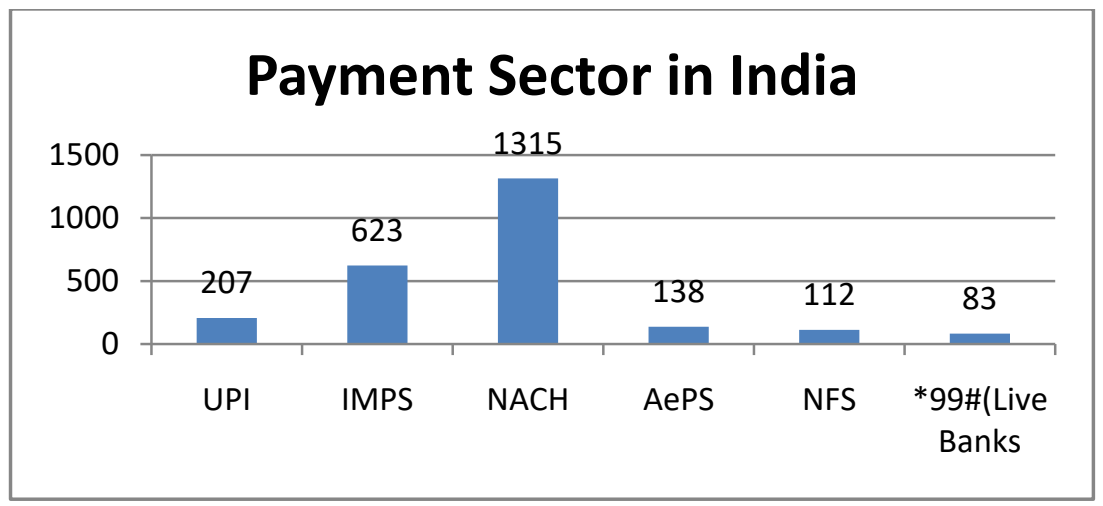

Figure 2: Payment Sector in India

Source: Annual Report of RBI 
During the period of 2015, RBI released some instructions to replace all existing magnetic stripes only cards with EuroPay, Mastercard \& VISA (EMV) chip \& PIN based cards by 2018 ending in the month of March.

In 2015-16 RBI sort out an initiative so as to boost origination in payment \& settlement systems by making announcement for PSIA (Payment System Innovation Awards) in 2015 December sponsored by IDRBT. The transactions along with bill payments are being taken into consideration. Payment gateways \& aggregators considered under BBPs (Bharat Bill Payment System).

In 2018-19 RBI introduced a process named 'Tokenisation' in which a card's16digit PAN is replaced with a unique alternate code (token) and a payment is being performed using token, instead of actual card data being captured at merchant's end. This step was taken to save the customer's data that could be at risk and susceptible to be misused by fraudsters.

According to a survey that has been reported by DSIM (Department of Statistics \& Information Management) in which 6 metropolitan cities were interrogated regarding the retail payments habits. Approximately 6000 respondents were there amongst which $96.3 \%$ were aware about digital payments with good educational background. Cash mode was out to their preference for making or receiving payment transactions. Around $8 \%$ of total respondents only shared their passwords while $45 \%$ of them were from categories that have never changed their PIN/OTP/Pass codes.

Indian Financial Technology \& Allied Services (IFTAS) set up by IDRBT (Institute for Development \& Research in Banking Technology) in February 2015 U/S 8 of Companies Act, 2013, on the recommendation of the Rang Rajan committee (2009).

In 2019-20, RBI set up an organization to increase the acceptance for both physical and digital PoS in the country, named Payments Infrastructure Development Fund (PIDF).

2.2 ECS (Electronic Clearing Services) - The payment system got an edge with the development of Unified Payment Interface (UPI). During the year 2015 and till now everyday has been proved to be a game changer in terms of the technological advancement. The data table that has been taken into consideration is ranging within the time period of 2015-2020 so as to see the adaptive changes in the rage.

NACH (National Automated Clearing House) operated by NPCI (National Payment Corporation of India) is included in ECS system. 
Table 1: ECS Dr. Cr. Values

\begin{tabular}{|c|c|c|c|c|}
\hline & \multicolumn{2}{|l|}{ ECS Dr } & \multicolumn{2}{|l|}{ ECS Cr } \\
\hline Years & Volume (Mn) & Value (Bn) & Volume (Mn) & Value (Bn) \\
\hline 2015-16 & 224.8 & 1652 & 39 & 1059 \\
\hline 2016-17 & 8.8 & 39 & 10.1 & 144 \\
\hline 2017-18 & 1.5 & 10 & 6.1 & 115 \\
\hline 2018-19 & 0.9 & 12.6 & 5.4 & 132.35 \\
\hline 2019-20 & 18 & 5145 & 1 & 39 \\
\hline
\end{tabular}

Source: Annual Report of RBI

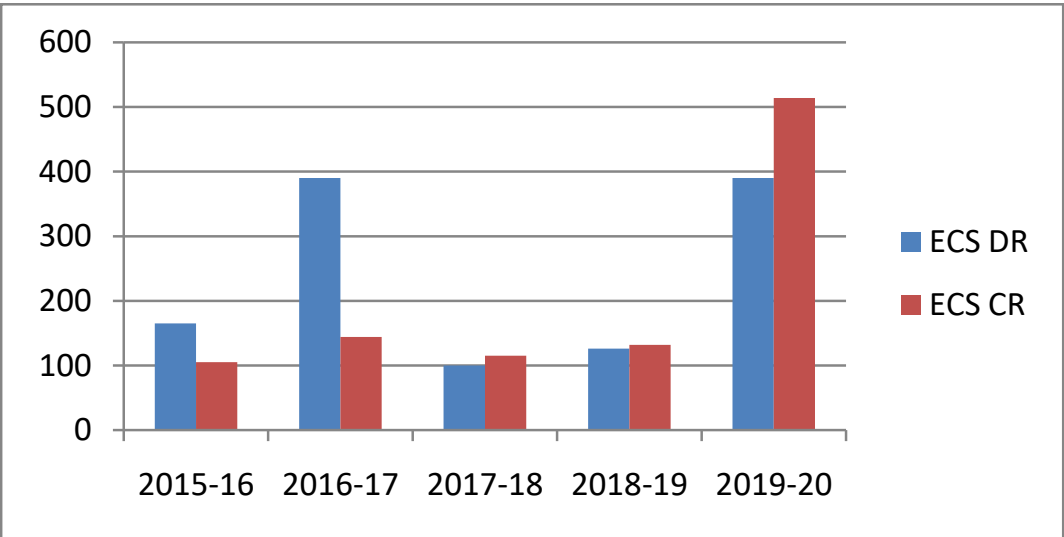

Figure 3

2.2 NEFT (National Electronic Fund Transfer) - In 2019-20, NEFT was operating in the batches of $24 * 7 * 365$, with effect from December 16, 2019. It's a unique retail payment system in the whole world. NEST facilities were made available in 217 banks having 1,53,311 branches/offices under administration.

As per the annual report of Reserve Bank of India of 2019-20, the volume of transactions has reached 2624 lakhs which showed an increment the efficiency of the payment systems with 48 batch settlements per day.

Table 2: NEFT

\begin{tabular}{|c|c|c|}
\hline Years & Volume (Mn)) & Value (Bn) \\
\hline $2015-16$ & 1252.9 & 83273 \\
\hline $2016-17$ & 1622 & 120040 \\
\hline $2017-18$ & 1946.4 & 172229 \\
\hline $2018-19$ & 2318.9 & 227936 \\
\hline $2019-20$ & 27445 & 22945580 \\
\hline
\end{tabular}

Source: Annual Report of RBI 


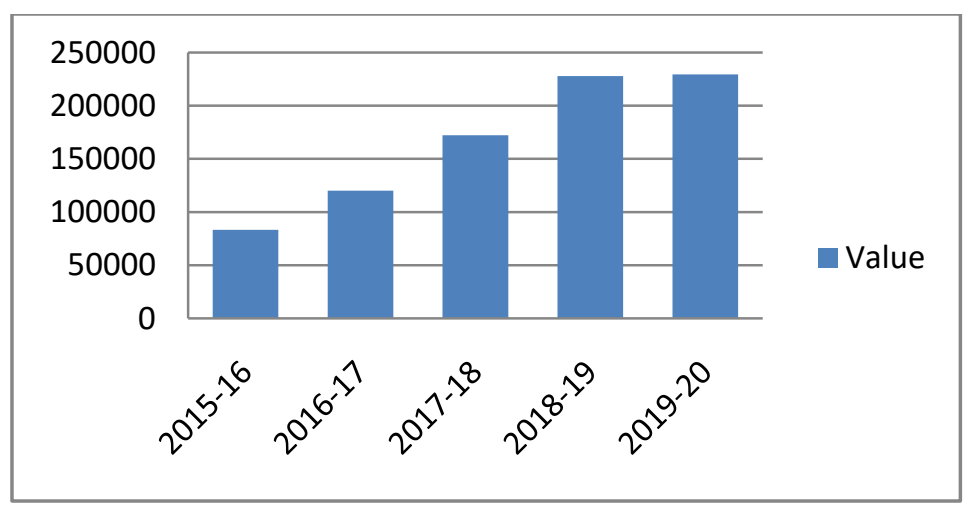

Figure 4

2.3 CBC (Card Based Clearing) - During 2016-17, contactless card payment were introduced like Samsung Pay and also got approval from RBI. To aware and promote more merchants and to ensure sustainability of the business the MDR (Merchant Discount Rate) framework had been introduced effectively from $1^{\text {st }}$ January, 2018. EMV chip based transactions are in rage now days to improve security system.

Table 3: CBC Values

\begin{tabular}{|c|c|c|c|c|}
\hline & \multicolumn{2}{|c|}{ Credit Cards } & Debit Cards \\
\hline Years & Volume (Mn)) & Value (Bn) & Volume (Mn)) & Value (Bn) \\
\hline $2015-16$ & 785.7 & 2407 & 1173.5 & 1589 \\
\hline $2016-17$ & 1087.1 & 3284 & 2399.3 & 3299 \\
\hline $2017-18$ & 1405.2 & 4590 & 3343.4 & 4601 \\
\hline $2018-19$ & 1762.6 & 6033 & 4414.3 & 5935 \\
\hline $2019-20$ & 2177.3 & 7308 & 5123.9 & 8048 \\
\hline
\end{tabular}

Source: Annual Report of RBI

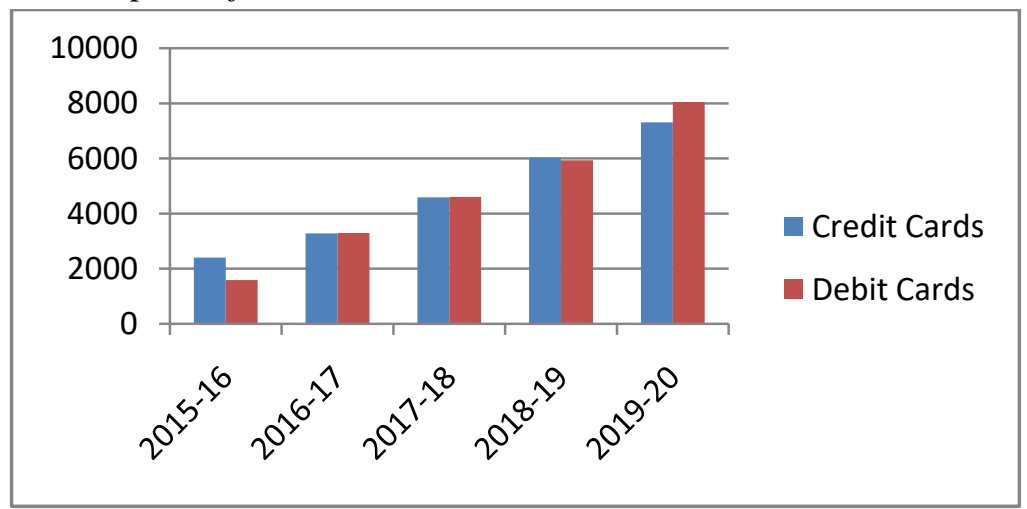

Figure 5

2.4 RTGS (Real Time Gross Settlement)- During 2015-16 the RBI identified the RTGS as one of the major principles of FMIs (Financial Market Infrastructure) and from then only its assessment had initiated. The RTGS charges were rationalized to be appropriately priced in banks against the services been provided to the customers. In 2016-17, banks initiated a positive feature of confirmation for RTGS 
transactions to ease customer's transactions. Endpoint security introduced in 201718 so a sto reduce the risk of fraudulent practices in wholesale payments. And then came NG-RTGS (Next Generation RTGS) to build multi-transactional point without any delay in processing. During 2019-20 approx 153605 branches of 218 banks were having this facility.

Table 4: RTGS

\begin{tabular}{|c|c|c|}
\hline Years & Volume (Mn) & Value (Bn) \\
\hline $2015-16$ & 98.3 & 824578 \\
\hline $2016-17$ & 107.8 & 981904 \\
\hline $2017-18$ & 124.4 & 1167125 \\
\hline $2018-19$ & 136.6 & 1356882 \\
\hline $2019-20$ & 150.7 & 1311564 \\
\hline
\end{tabular}

Source: Annual Report of RBI

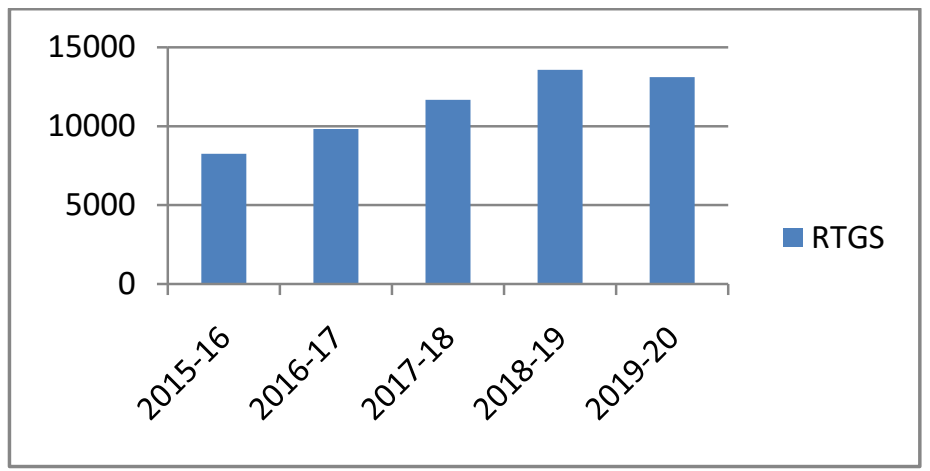

Figure 6

\section{Comparative Analysis of Various Payment Systems (2015-2020)}

3.1 2015-2016- During 2015-16, the estimated ECS Cr was 1059 billion whereas ECS Dr was 1652 billion, NEFT was 83273 billion, Card based Clearing was 1589 in Debit Cards and 2407 billion in Credit cards and RTGS transactions in the value was 8250 billion. PPIs valued at 488 billion that was higher in comparison to the previous year because of the introduction of PPI-MTS (Mass Transit System) for facilitating the consumers to make small value electronic payments.

3.2 2016-2017- During 2016-17, the non-cash payments goes up in terms of epayment up to $89 \%$ as compared to $84 \%$ in the previous year. ECS Dr was 39 billion and ECS Cr was 144 Billion, NEFT was 120,040 billion, CBC was 3299 billion in Debit cards and 3284 in Credit cards, PPIs were 838 billion. RTGS transactions valued at 982 trillion and were made available in 198 banks. WLAN with WIPS (Wireless Intrusion Prevention System) installed and made operational successfully.

3.3 2017-2018- In 2017-18, the usage of paper-based clearing instruments decreased and continuous growing was recorded in the registered users of EPS through NEFT, IMPS, card and mobile banking transactions. Retail payments hiked up to 
92.6\%. RTGS was 1167 trillion, NEFT was 172 trillion, CBC was 1.4 billion in credit cards and 3.3 billion in debit cards, ECS Cr was 115 billion and ECS Dr was 10 billion.

3.4 2018-2019- The portion of electronic transactions in totality of retail payments increased to $95.4 \%$ in comparison with $92.6 \%$ in the previous year. RTGS was 11357 trillion, ECS Dr was 12.6 billion and ECS Cr was 132.35 billion, CBC was 1.8 billion in credit cards and 4.4 billion in the category of debit cards, NEFT was 227,936 billion, PPIs were 212.9 billion and UPI valued at 8770 billion. There is an enhanced usage of SFMS (Structured Financial Messaging System) in RTGS and NEFT systems. Next generation RTGS used the ISO-20022 in SFMS.

3.5 2019-2020- The system of Payment \& settlement grown by $44.1 \%$ more in comparison with $55.8 \%$ in the previous year. The valuation also got enhanced by 5.4\%. RTGS was 1311.6 lakh crores. NEFT was 2.29 billion, ECS Cr was 5145 billion and ECS Dr was 39 billion, CBC was 7.3 million in Credit cards and 8 million in Debit cards. PPIs were 2 million and UPIs were 21 billion. Due to Covid-19 pandemic, a major downfall has been witnessed in digital transactions in India.

\section{Objectives of the study-}

The main objective of this research article is -

1. To observe the growth of Electronic payment sector in India.

2. To study the gap between traditional payment services and e-payment services.

3. To summarize various digital payment methodologies and variations in the data been provided by the RBI in the annual report and Fintech reports for a specified period i.e., (2015-2020).

\section{Research Methodology-}

The study has been done on the basis of annual report of RBI and the time period is ranging from the year 2015-2020. The previous study from the year 2010-2015 has been done by S.Abid (2016) from which I got an opportunity to move this analysis for understanding the developing criterias in electronic payment and financial technology. I have taken the data over EPS, NEFT, RTGS, CBC to capture an overall scenario picture of payment and settlement sector.

Data Collection- It has been done by means of the annual reports of RBI, NASSCOM reports and Fintech report of 5 years. These secondary sources made a strong foundation for future research as well as the current and upcoming trends over financial technology. 


\section{Findings}

It has been found that the payment and settlement systems benchmarked a robust growth during the period 2019-20, which has been growing by 44.1 per cent in terms of volume and topped in terms of expanding business by 55.8 per cent in the year 2018-19. If we talk about the value, it increased by 5.4 per cent on top of 14.2 per cent in the previous year, mainly due to lower growth observed in the valuation that was observed in Real Time Gross Settlement (RTGS) system. There can be seen a lion's share of digital transactions in the total volume of non-cash retail payments which has been increased to 97.0 per cent during 2019-20, up from 95.4 per cent in the previous year (Table 5). Due to the major financial crisis during COVID-19 pandemic, a downfall in digital payments occurred in lockdown globally and it affected all the economic activities to a great extent.

\begin{tabular}{|c|c|c|c|c|c|c|}
\hline \multicolumn{7}{|c|}{ Table 5: Payment System Indicator-Annual Turnover } \\
\hline Items & \multicolumn{3}{|c|}{ Volume(Million) } & \multicolumn{3}{|c|}{ Value(INR Billion) } \\
\hline 1 & 2017-18 & 2018-19 & $2019-20$ & 2017-18 & 2018-19 & 2019-20 \\
\hline A. Settlement Systems & 2 & 3 & 4 & 5 & 6 & 7 \\
\hline CCIL Operated Systems & 35 & 36 & 36 & $10,74,80,202$ & $11,65,51,038$ & $13,41,50,192$ \\
\hline B. Payment Systems & & & & & & \\
\hline $\begin{array}{l}\text { 1. Large Value Credit Transfers } \\
\text { - RTGS }\end{array}$ & 1,244 & 1,366 & 1,507 & $11,67,12,478$ & $13,56,88,187$ & $13,11,56,475$ \\
\hline Retail Segment & & & & & & \\
\hline 2. Credit Transfers & $\begin{array}{l}58,793 \\
\end{array}$ & $1,18,750$ & $2,06,661$ & $1,88,14,287$ & $2,60,97,655$ & $2,85,72,100$ \\
\hline 2.1 AePS (Fund Transfers) & 6 & 11 & 10 & 300 & 501 & 469 \\
\hline $2.2 \mathrm{APBS}$ & 12,980 & 15,032 & 16,805 & 55,949 & 86,734 & 99,448 \\
\hline $2.3 \mathrm{ECS} \mathrm{Cr}$ & 61 & 54 & 18 & 11,864 & 13,235 & 5,145 \\
\hline 2.4 IMPS & 10,098 & 17,529 & 25,792 & $8,92,498$ & $15,90,257$ & $23,37,541$ \\
\hline $2.5 \mathrm{NACH} \mathrm{Cr}$ & 7,031 & 9,021 & 11,406 & $5,20,992$ & $7,36,349$ & $10,52,187$ \\
\hline 2.6 NEFT & 19,464 & 23,189 & 27,445 & $1,72,22,852$ & $2,27,93,608$ & $2,29,45,580$ \\
\hline 2.7 UPI & 9,152 & 53,915 & $1,25,186$ & $1,09,832$ & $8,76,971$ & $21,31,730$ \\
\hline $\begin{array}{l}\text { 3. Debit Transfers and Direct } \\
\text { Debits }\end{array}$ & 3,788 & 6,382 & 8,957 & $3,99,300$ & $6,56,232$ & $8,26,036$ \\
\hline 3.1 BHIM Aadhaar Pay & 20 & 68 & 91 & 78 & 815 & 1,303 \\
\hline $3.2 \mathrm{ECS}$ Dr & 15 & 9 & 1 & 972 & 1,260 & 39 \\
\hline $3.3 \mathrm{NACH}$ Dr & 3,738 & 6,299 & 8,768 & $3,98,211$ & $6,54,138$ & $8,24,491$ \\
\hline $\begin{array}{l}\text { 3.4 NETC (Linked to Bank } \\
\text { Account) }\end{array}$ & 15 & 6 & 97 & 39 & 20 & 203 \\
\hline 4. Card Payments & 47,486 & 61,769 & 73,012 & $9,19,035$ & $11,96,888$ & $15,35,765$ \\
\hline 4.1 Credit Cards & 14,052 & 17,626 & 21,773 & $4,58,965$ & $6,03,413$ & $7,30,895$ \\
\hline 4.2 Debit Cards & 33,434 & 44,143 & 51,239 & $4,60,070$ & $5,93,475$ & $8,04,870$ \\
\hline 5. Prepaid Payment Instruments & 34,591 & 46,072 & 53,318 & $1,41,634$ & $2,13,323$ & $2,15,558$ \\
\hline 6. Paper-based Instruments & 11,713 & 11,238 & 10,414 & $81,93,493$ & $82,46,065$ & $78,24,821$ \\
\hline $\begin{array}{l}\text { Total - Retail Payments } \\
(2+3+4+5+6)\end{array}$ & $1,56,371$ & $2,44,211$ & $3,52,362$ & $2,84,67,748$ & $3,64,10,163$ & $3,89,74,281$ \\
\hline Total Payments $(1+2+3+4+5+6)$ & $1,57,615$ & $2,45,577$ & $3,53,869$ & $14,51,80,226$ & $17,20,98,350$ & $17,01,30,756$ \\
\hline
\end{tabular}


It should be noted that-

1. Only customer-oriented and inter-bank transactions are being included in Real Time Gross Settlement (RTGS) system.

2. Settlements of the Collateralised Borrowing and Lending Obligation, government securities and forex transactions are through the Clearing Corporation of India Ltd. (CCIL).

3. Government Securities include outright trades and both legs of repo transactions and triparty repo transactions.

4. With effect from November 5, 2018, CCIL discontinued CBLO and operationalised triparty repo under securities segment.

5. The figures for cards are for payment transactions at point of sale (POS) terminals and

online.

Source: RBI Annual Report 2017-2020

\section{Limitations of the Study}

The study could be done after considering some more financial reports to make the perspective more clear. The primary data could be collected by means of contacting some Fintech companies to make more transparent research.

\section{Conclusion \& Future Research}

E-Payment system is supported by RBI because of the reason in which it is observed that consumers are developing trust over the fact that their transactions are being backed with technological security support. Many fintech payment type start-ups are working to improve the user-friendly platforms to perform quick and easy transactions.

From this paper, not only the data trends are tried to show an edge of growth line from cash payments to card payments and also different payment.

Future research could be done on the basis of various e-payment applications and platforms that are being provided to satisfy customers and make them understand the best part of financial technology. Also an empirical study can be done over the pre and post Covid pandemic impacts on the digital payment arena. 


\section{References:}

1. Abid S. (2016). , Electronic Payment System: An Evolution in Indian Banking Sytem' e-ISSN: 2321-5933, pISSN: 2321-5925. Vol.7, 2, pp-25-30.

2. Arner, D., Barberis, J., \& Buckley, R. (2015). The evolution of fintech: a new post-crisis paradigm?

3. Blake M., \& Vanham, P. (2016). Five things you need to know about Fintech. World Economic Forum. Retrieved from https://www.weforum.org/agenda/2016/04/5-things-you-need-to-know-about-fintech/

4. Broom, D. (2015). Innovation in Payments: The Future is Fintech. New York City: BNY Mellon.

5. Buckley, Ross \& Arner, Douglas \& Barberis, Janos. (2016). The Evolution of Fintech: A New Post-Crisis Paradigm? Georgetown Journal of International Law. Retrieved from 47. 1271-1319. 10.2139/ssrn.2676553

6. Kang, Jungho. (2018). Mobile payment in Fintech environment: trends, security challenges, and services. Human-centric Computing and Information Sciences. Retrieved from 8. 10.1186/s13673-018-0155-4.

7. Khiewngamdee, Chatchai \& Yan, Ho-don. (2019). The Role of Fintech e-payment on APEC economic development. Journal of Physics: Conference Series. 1324. Retrieved from 012099. 10.1088/17426596/1324/1/012099.

8. MEDICI Fintech Report India, 2020. Retrieved from https://cms.iamai.in/Content/ResearchPapers/

9. India \#Digital Payments 2020 - Launching the First Adoption Index - Time is Now! Retrieved July 27, 2020 from https://community.nasscom.in/communities/digital-transformation/fintech/india-digital-payments-2020launching-the-first-adoption-index-time-is-now.

10. “Evolution of Fintech". Retrieved $3^{\text {rd }}$ July, 2019 from https://www.e-zigurat.com/

11. Murad, A. (2015, October 14). Start-ups aim at banks' income streams. Retrieved November 2, 2017, from https://www.ft.com/content/55049480-61cb-11e5-9846-de406ccb37f2

12. NPCI - National Payments Corporation of India. Retrieved from https://www.npci.org.in/

13. Annual Reports of The RBI. Retrieved from https://www.rbi.org.in/Scripts/AnnualReportMainDisplay.aspx

14. Xiaogang Chen, Libo Su, Darrell Carpenter. (2020) Impacts of Situational Factors on Consumers' Adoption of Mobile Payment Services: A Decision-Biases Perspective. International Journal of Human-Computer Interaction 36:11, pages 1085-1093. 